\title{
Assessment of Pig Production and Constraints in Mecha District, Amhara Region, Northwestern Ethiopia
}

\author{
Yeshambel Mekuriaw and Bimrew Asmare \\ Department of Animal Production and Technology, College of Agriculture and Environmental Sciences, Bahir Dar University, \\ P.O. Box 79, 100 Bahir Dar, Ethiopia
}

Correspondence should be addressed to Bimrew Asmare; bimasm2009@yahoo.com

Received 13 June 2014; Revised 12 October 2014; Accepted 13 October 2014; Published 17 November 2014

Academic Editor: Albino Maggio

Copyright (C) 2014 Y. Mekuriaw and B. Asmare. This is an open access article distributed under the Creative Commons Attribution License, which permits unrestricted use, distribution, and reproduction in any medium, provided the original work is properly cited.

\begin{abstract}
The study was undertaken in Mecha District, Amhara National Regional State, Northwestern Ethiopia, in 2012/2013. The objectives of the study were to assess production purpose and management practices of pig and to identify constraints and generate baseline information for further research and development. From the district, 6 Kebeles (name of local administration in Ethiopia) were identified and from each Kebele 15 households were selected making the number of respondents 90. A pretested semistructured questionnaire was employed for collecting data through interview and face to face discussion with the pig owners including key informant group discussion and secondary sources. Multivisits to study sites were also made to observe the feeding, housing, and other pig management practices. The results indicated that the purpose of pig production is mainly targeted for additional income and profit for the household in which pigs are sold for external markets as pork is not consumed by local community. Results indicate that pig keepers were farmers or nonfarmers with small land holding and people engaged in other types of work. The major feed source for pig was grazing, followed by crop residue feeding and supplementing with household and agricultural by-products. Pigs are kept in house at least for the night, though the pig house was not separated by age or physiological stage. The most important constraints of pig production in the study area were feed shortage, poor access to veterinary services, and poor market linkage.
\end{abstract}

\section{Introduction}

The growth of population, urbanization, and rising income in many parts of the developing world is believed to result in a growing demand for animal products [1]. It has been stated that, among food problems, shortages of animal protein are a major problem in Africa [2]. Consequently, there has been a rise in the production of animal products, particularly from poultry and pigs in the world. With the increase in worldwide demand for meat, fast-growing species with efficient feed conversion rates such as pigs are likely to account for a major share in the growth in the livestock subsector. Pig farming is an important task which provides opportunity as an income generating activity for small-scale farmers, especially in developing countries. This activity is most popular in Africa, Latin America, and South East Asia [3]. In most cases, the reasons for keeping pigs include provision of protein/meat, dowry, and manure for fertilising the soil, particularly for farmers that practice mixed farming.

Pig production in developing counties is characterized by traditional small scale subsistence driven production systems in which pigs provide much more than meat unlike in western countries where pig production is based on human edible foods. Pigs in such low-input systems provide value added for farmers by consuming feed that would otherwise be wasted. Hence, pork might contribute to food security and provide protein, but the animals might also constitute a financial safety net, fulfill a role in cultural traditions, or provide additional cash for school fees, medical treatment, or small investments. The domestic pig is an animal which has been very much neglected by the scientific community in Ethiopia; hence very few publications are available focusing mainly on gastrointestinal parasites $[4,5]$; prevalence of tuberculosis [6]; and production system and constraints in 
Tigray region [7]. Although pig production is less common in Ethiopia, small scale farmers with few pigs are not uncommon in towns and cities of Ethiopia. It has been observed that there is an emergence of smallholder farmers in Northwestern Ethiopia who raise few pigs in additional to agricultural and nonagricultural activities (personal observation).

However, there are no information about purpose of pig production, management of pig, and constraints of these pig producers in the study area. This will help as baseline information for future research and development interventions of pig subsector. In addition, these data may provide useful information for future research and development interventions in the pig sector. Hence, the objectives of this assessment were to examine the role pig production and its status, management practices of pig, and challenges of producers in Mecha district, Western Gojjam Zone, Amhara Region, Ethiopia.

\section{Materials and Methods}

The study was undertaken in Amhara National Regional State (ANRS) at Mecha District in 2012/2013. The study site was chosen based on the pig population and production practices. A total of 6 Kebeles associations and 90 households were purposively selected and used in the study. Semistructured questionnaire was employed for data collection and supported with key informant group discussion. Different data were collected from both primary and secondary sources. The primary data included household characteristics of producers, major livestock holding, pig holding, types of feeds and feeding management, and housing and health management of pig. The data collected was analyzed using descriptive statistics with SPSS software version 16.

\section{Results and Discussion}

3.1. Age and Sex Characteristics. The age characteristic of households is shown in Table 1 . The result indicates that the majority of pig keepers in the study area were males $(86.7 \%)$ with small proportion of females (13.3\%).

The majority of the respondents were between ages 21 and 39 years (Table 1). This range is the active working age and so would include those who have gone to seek offfarm activities in a periurban area. The majority of the younger group members combine pig farming with nonfarm jobs. The advantage of these types of age groups engaged in livestock activities will help in easy technology transfer easily as youth are more flexible to new techniques and applications.

3.2. Educational Characteristics of Respondents. The educational status of pig keepers in the study area is shown in Table 2. The majorities of pig keepers in the study area are literate people from read and write up to diploma level (80\%) with few illiterate groups (20\%) These kinds of educational status may facilitate the implementation of more appropriate farming procedures.
TABLE 1: Age structure of pig producer respondents $(N=90)$.

\begin{tabular}{lc}
\hline Age category & Percentage $(\%)$ \\
\hline$<20$ years & 6.7 \\
$20-29$ years & 33.3 \\
$30-39$ years & 33.3 \\
$40-49$ years & 6.7 \\
$>60$ years & 13.3 \\
\hline Total & 100.0 \\
\hline
\end{tabular}

TABLE 2: Educational status of respondents $(N=90)$.

\begin{tabular}{lc}
\hline Education category & Percent (\%) \\
\hline Illiterate & 20.0 \\
Read and write & 20.0 \\
Elementary school & 26.7 \\
High school & 6.7 \\
Diploma and above & 20.0 \\
\hline Total & 100.0 \\
\hline
\end{tabular}

TABLE 3: Off-farm income characteristics of respondents $(N=90)$.

\begin{tabular}{lc}
\hline Off-farm income & Percent (\%) \\
\hline Livestock fattening & 33.2 \\
Trade & 20 \\
No off-farm income & 13.3 \\
Office work & 13.4 \\
Barber & 6.7 \\
Butcher & 6.7 \\
Mill worker & 6.7 \\
\hline Total & 100.0 \\
\hline
\end{tabular}

3.3. Land Holding and Off-Farm Income. The data indicated that $46.7 \%$ of respondents owned a piece of land, while $53.3 \%$ were landless farmers or people engaged in other types of work. The average land size of a pig keeper was 0.33 ha with a range of 0.12 to 1 ha which is less than the national average is. The occupational status of pig keepers in the study area is shown in Table 3. The distribution according to occupation revealed that in addition to farming most farmers are engaged in a variety of off-farm activities with livestock fattening being the highest $(33.2 \%)$ proportion followed by trade $(20 \%)$ and office work (13.4\%).

3.4. Livestock and Pig Ownership Status of Respondents. The proportion of animal species owned by respondents is shown in Table 4. Pig ownership per household is the second following beekeeping and pig ownership is comparable to other livestock species owned by producers which in turn indicates that pig production is an alternative form of animal farming to generate household income in the study area. This is due to the fact that pigs are highly prolific and require less 

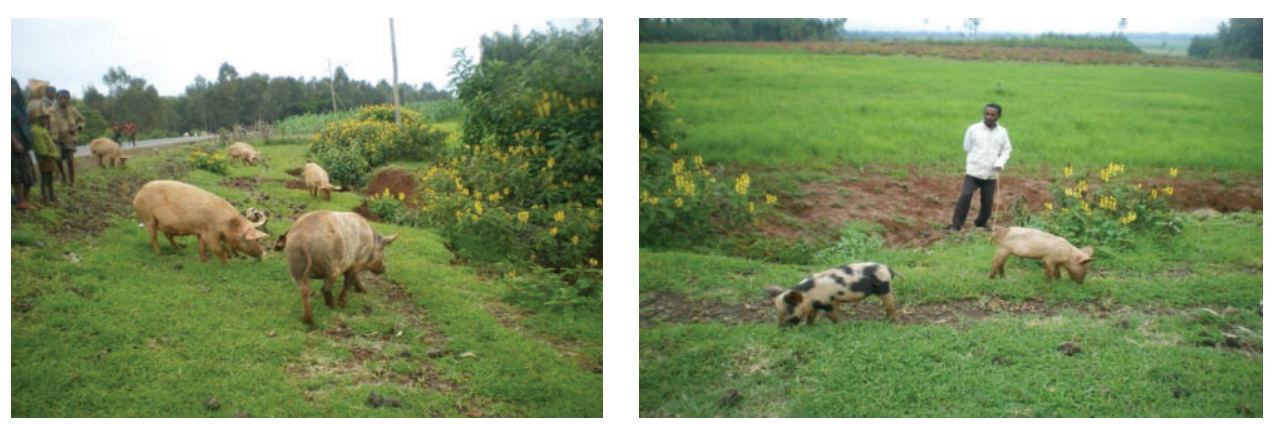

FIGURE 1: Pigs grazing on roadside around Merawi town (Mecha District) in rainy season.

TABLE 4: Livestock holding of pig keeper respondents $(N=90)$.

\begin{tabular}{lc}
\hline Livestock species & Percent (\%) \\
\hline Beekeeping & 73.3 \\
Shoat & 6.7 \\
Dairy & 6.7 \\
Beef & 6.7 \\
Only pig & 6.7 \\
\hline Total & 100.0 \\
\hline
\end{tabular}

capital and are new ventures of livestock production which improve socioeconomic condition of people in the study area.

\subsection{Management Practice of Pig}

3.5.1. Purpose of Pig Keeping. Pig keeping in Mecha District area is a recently introduced livestock production as most $(68 \%)$ of respondents have experience of pig keeping from less than a year with an average experience of 3.5 years. This indicates that pig keeping is an emerging livestock production. All of the respondents (100\%) assured that the purpose of pig keeping in the study area was for profit and extra income. With regard to the advantage of pig farming, the majority of respondents ranked because of its less land requirement as first $(46.7 \%)$ followed by less capital (40\%) and prolificacy $(13.3 \%)$.

The result of this assessment indicated that all of the respondents (100\%) assured that the purpose of pig keeping in the study area was for profit and extra. All pig owners were against the slaughter of pigs for home consumption. This is an indication that, in Ethiopia, religion, culture, and traditions play an important role in the pig sector $[7,8]$. Hence, pig production and consumption are not widespread in the study area. This is in agreement with the finding of Ethiopian workers [7] and in contrast to the situation in Namibia, Uganda, and Kenya where pig keeping is for income and pork consumption $[9,10]$. This in turn explains the lack of local market and in turn calls market orientation towards organized export market and value creation.

3.5.2. Feeding and Watering of Pigs. The major feed resources of pig feeds as ranked by keepers were grazing (46.7\%)
TABLE 5: Feed sources of pig $(N=90)$.

\begin{tabular}{lc}
\hline Feed source & Percent (\%) \\
\hline Grazing & 46.7 \\
Crop residues & 26.7 \\
Household offals & 20.0 \\
Supplements/grain & 6.7 \\
\hline Total & 100.0 \\
\hline
\end{tabular}

followed by crop residues (26.7\%) and household offal (20\%) (Table 5). Pig grazing on the grass field is common in both dry and wet seasons of the year, according to respondents. The dominant crop residue used for pig feed according to the respondents is maize stalk $(46.7 \%)$ followed by millet straw (33.3\%) and teff straw (13.3\%). Pig were observed roaming and feeding on different feed resources and this may be related to the fact that pig tends to graze in the field than be confined in the confinement, which in turn reflects that the pig production system is more extensive in the study area like other livestock species. Figure 1 shows pigs roaming and grazing on different feed resources.

Among the types of feeds supplements given to pig, brewer's by-products are more preferred followed by milling by-products and grain and grain by-products and household offal. Feed conservation is not a common practice in the study area; as a result pig faces feed shortage both in dry season and in wet season. The dominant crop residue for pig in the study area is maize stalk (93.3\%). This is the major feed during dry season according to respondents. Almost all producers provide supplementary feed for lactating sows especially in dry season. Salt provision is also common. Figure 2 shows pigs roaming around the homestead in study area.

Pig were observed roaming and feeding on different feed resources and this may be related to the fact that pig tends to graze in the field than be confined in the confinement, which in turn reflects that the pig production system is more extensive in the study area. Grazing is common both in dry and in wet season in the study area. This is in agreement with other findings [4,7]. In Namibia reports [9] indicates that $98 \%$ of pig producers fed their animals on home remnants and allowed them to scavenge and rural farmers fed their pigs 


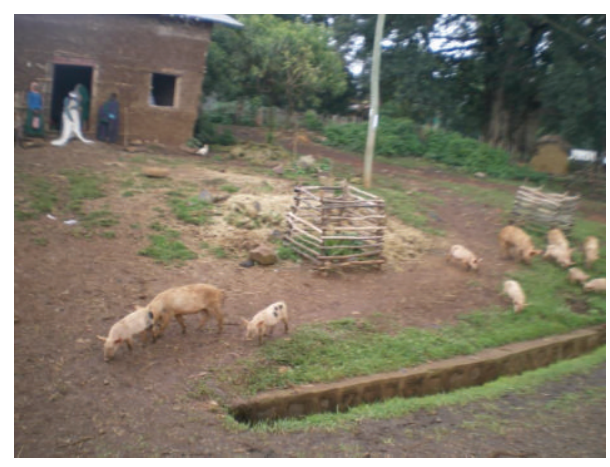

FIGURE 2: Pigs roaming around the homestead in study area.

on what was available without regard to their age, sex, and production stages. According to researches [5] indicates that the domestic pig has a role in the epidemiology of important zoonotic diseases such as Ascaris and Cryptosporidium spp. and as a reservoir host of Fasciola hepatica, an economically important parasite of ruminants. Also the works of Arega et al. [6] isolated M. tuberculosis, an emerging zoonotic disease, at prevalence rate of $5.8 \%$ in pigs slaughtered at two abattoirs in central Ethiopia, suggesting the existence of possible risk of interspecies transmission particularly between pigs and humans. This situation has to be taken as critical taking the association between TB and HIV [6].

3.5.3. Pig of Housing. All pig keepers (100\%) house the animals indoor during the night to protect them from predation and rustling. From the total of respondents only $20 \%$ have separate piglet houses, while the remaining keep piglets with adult pigs. The types of houses used by pig keepers are corrugated iron roof (80\%), bamboo roof $(13.3 \%)$, and thatched roof $(6.7 \%)$ with wooden wall and mud floor. Figure 3 shows traditional housing of pigs on mud floor and wooden wall. Most of pig producers clean their pig house once a day (46.7\%), some twice a day (26.7\%), and the remaining once a week (26.7\%). All pig keepers (100\%) in the study area responded that they keep pig in a house in night time in corrugated and thatched roof mud wall houses. The house is usually meant to keep pig from predators at night and from theft. The pig house is not separate by age or physiological stage of pig. Although pig keepers clean their pig house, the cleaning frequency is variable. According to the respondents, the pig house cleaning frequency is that some clean twice a day (26.7\%), most of them once a day (46.7\%), and the remaining once a week $(26.7 \%)$. On the other hand, the results of Tomass et al. [5] pointed out that the integration of pigs into the traditional mixed farming system might contribute to disease transmission taking the role of pigs as reservoirs of diseases. However, separation of various age and sex groups and classes of pigs has great advantage in feeding and management which will help to improve growth because it will help to avoid competition among animals [11].

3.5.4. Pig Health Management. From the total of local producers only $73.3 \%$ have access to veterinary services, while

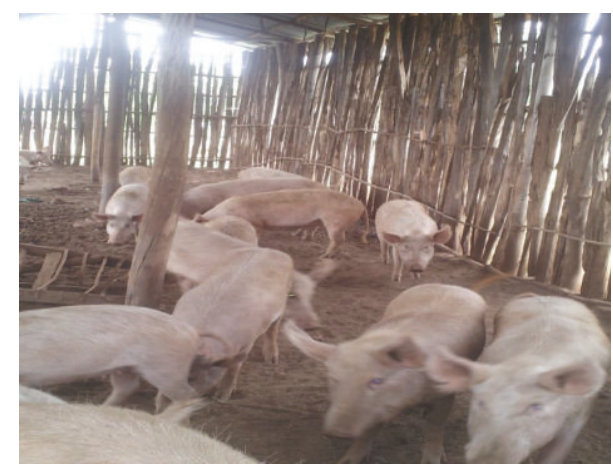

FIGURE 3: Traditional housing of pigs on mud floor and wooden wall.

the remaining $26.7 \%$ had no access to veterinary services. But pig keepers do not have the same management of sick pig. From the total of respondents only $20 \%$ consult veterinarian while others (46.7\%) keep waiting without doing anything, use traditional medicine (20\%), or cull their animals (13.3\%). Mortality of pig in the study area is a problem in the study area as $20 \%$ of respondents faced pig mortality. From the total of respondents $60 \%$ are affected by distance from veterinary clinic, $26.7 \%$ are affected by cost, and $13.3 \%$ are constrained by lack of veterinary drugs for pig. Another problem is farrowing difficulty which is observed in many of pig keepers. $46.7 \%$ of pig keepers reported that they face foaling difficulty which is still abortion (53.7\%). This may be due to inappropriate feeding, housing, and health care systems applied on pregnant sows.

3.5.5. Reproductive Management. The average litter size was 7 piglets per sow ranging from 4 to 12 which is similar to other studies for extensive production systems. The majority of pig keepers $(93.3 \%)$ used weaning practice while the remaining (6.7\%) do not. The weaning age of piglet varied between 3 and 3.5 weeks. Castration was employed by the $13.3 \%$ of pig producers. Castration of pig is less common. From the total of respondents only (13.3\%) practice castration whiles the majority $(86.7 \%)$ do not practice.

3.5.6. Constraints of Pig Keeping. The major constraints to pig production in the study areas reported according to their order of importance include feed availability and cost, shortage of water, cost of medicine, and lack of skilled veterinarians on pig diseases and poor preventive health care. Similar production constraints were reported [12] in Uganda and Namibia [11]. The production constraints might hinder improvement to productivity of pigs [13]. According to Ayele et al. [14], alleviating constraints to marketing, improving marketing and market information, and upgrading marketing infrastructures will potentially increase the welfare of smallholder producers and urban consumers and improve the national balance of payments. According to the findings of workers in Ethiopia [4], the government should also work on cultural and behavioral change of the people and also formulate an appropriate policy regarding pig production in the livestock production strategy. 
Also during key informant discussion it was reported that because of religious taboos for pork consumption in the country, producers have fear of poor domestic marketing potential. The government should also work on cultural and behavioral change of the people and also formulate an appropriate policy regarding pig production without delay and should be held in the national livestock development program $[4,9]$. Animal health constraints were perceived by farmers to be important with mange, worms, and leg paralysis being mentioned by the majority of the respondents (farmers). Other workers [7] explained that smallholder pig husbandry is a newly introduced livestock production in Ethiopia. This calls for further analysis of pig production practice, opportunities, and constraints of this subsector which in turn helps to design optimum husbandry systems.

\section{Conclusion}

Pig production is a recently introduced activity in Mecha district with traditional management based on scavenging type of feeding. The production system of pigs in the district, however, lacks proper pig husbandry practices such as feeding, housing, health care, and overall management efforts. This study revealed that the main purpose of production is to get additional income for the household. In addition, the study pointed that the pig farming in the study area enabled producers to generate additional income which in turn helps in achieving food security self-employment for landless and unemployed people in the study area. This assessment study is the only and first of its kind and has limitation in analysis of whole factors available in the farming system; hence, detailed socioeconomic and biological studies are expected afterwards. As pigs are among the animal species which are expected to fulfill the growing demand of meat in developing countries, better production system and value creation approaches should be introduced in the farming system.

\section{Recommendations}

(i) In-depth studies on the types of feeding trials, diseases, and parasites occurring in the study area will help much to boost pig productivity.

(ii) On-station and on-farm level scientific feeding management studies should be conducted in the future.

\section{Conflict of Interests}

The authors declare that there is no conflict of interests regarding the publication of this paper.

\section{Acknowledgments}

The authors thank the field workers especially the District Office of Agriculture and Mr. Shiferaw for data collection process.

\section{References}

[1] FAO, Statistical database of Food and Agriculture Organization of the United Nations, FAO, Rome, Italy, 2003, http://faostat .fao.org/.

[2] M. Mengesha, "Feed resources and chicken production in Ethiopia," World's Poultry Science Journal, vol. 68, no. 3, pp. 491502, 2012.

[3] T. Huynh, A. J. A. Aarnik, A. Drucker, and M. W. A. Verstegen, "Swine production in Cambodia, Laos, Philippines, and Vietnam: a review," Asian Journal of Agriculture and Development, vol. 4, no. 1, pp. 323-339, 2007.

[4] S. Abdu and A. Gashaw, "Production system dynamism and parasitic interaction of swine in and around Holetta, Ethiopia," Ethiopian Veterinary Journal, vol. 14, pp. 71-81, 2010.

[5] Z. Tomass, E. Imam, T. Kifleyohannes, Y. Tekle, and K. Weldu, "Prevalence of gastrointestinal parasites and Cryptosporidium species in extensively managed pigs in Mekelle and urban areas of southern zone of Tigray region, Northern Ethiopia," Veterinary World, vol. 6, no. 7, pp. 433-439, 2013.

[6] S. M. Arega, F. J. Conraths, and G. Ameni, "Prevalence of tuberculosis in pigs slaughtered at two abattoirs in Ethiopia and molecular characterization of Mycobacterium tuberculosis isolated from tuberculous-like lesions in pigs," BMC Veterinary Research, vol. 9, article 97, 2013.

[7] T. Tekle, A. Tesfay, and T. Kifleyohannes, "Smallholder swine production and its constraints in Mekelle and southern zone of Tigray region, north Ethiopia," Livestock Research for Rural Development, vol. 25, no. 10, 2013.

[8] F. K. Mutua, C. E. Dewey, S. M. Arimi, E. Schelling, W. O. Ogara, and M. Levy, "Reproductive performance of sows in rural communities of Busia and Kakamega Districts, Western Kenya," African Journal of Agricultural Research, vol. 6, no. 31, pp. 64856491, 2011.

[9] MoARD (Ministry of Agriculture and Rural Development of Government of Ethiopia), Livestock Development Master Plan Study. Phase I Report-Data Collection and Analysis. Volume B-Meat Production, GRM International BV, 2007.

[10] N. P. Petrus, I. Mpofu, M. B. Schneider, and M. Nepembe, "The constraints and potentials of pig production among communal farmers in Etayi Constituency of Namibia," Livestock Research for Rural Development, vol. 23, no. 7, 2011.

[11] G. C. Banerjee, A Textbook of Animal Husbandry, Oxford and IBH Publishing Co. Pvt. Ltd., New Delhi, India, 8th edition, 2010.

[12] D. Muhanguzi, V. Lutwama, and F. N. Mwiine, "Factors that influence pig production in Central Uganda-case study of Nangabo Sub-County, Wakiso district," Veterinary World, vol. 5, no. 6, pp. 346-351, 2012.

[13] J. K. Wabacha, J. M. Maribei, C. M. Mulei, M. N. Kyule, K. H. Zessin, and W. Oluoch-Kosura, "Characterisation of smallholder pig production in Kikuyu Division, central Kenya," Preventive Veterinary Medicine, vol. 63, no. 3-4, pp. 183-195, 2004.

[14] S. Ayele, W. Assegid, M. A. Jabbar, M. M. Ahmed, and H. Belachew, Livestock Marketing in Ethiopia: A Review of Structure, Performance and Development Initiatives, Socio-Economics and Policy, Addis Ababa, Ethiopia, 2003.

[15] A. Haileyesus, The prevalence of intestinal parasites and molecular characterization of Cryptoporidium species in Ethiopia [Ph.D. thesis], Addis Ababa University, Addis Ababa, Ethiopia, 2010. 


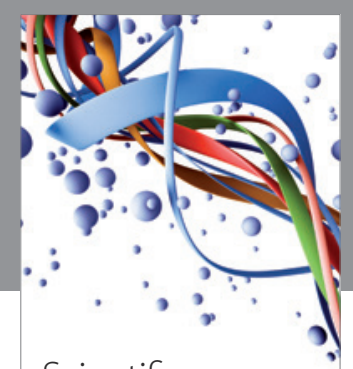

Scientifica
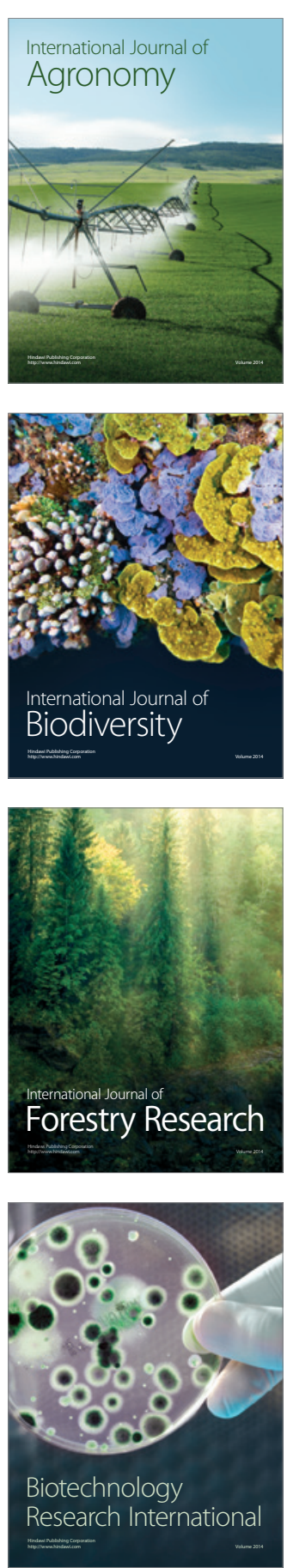
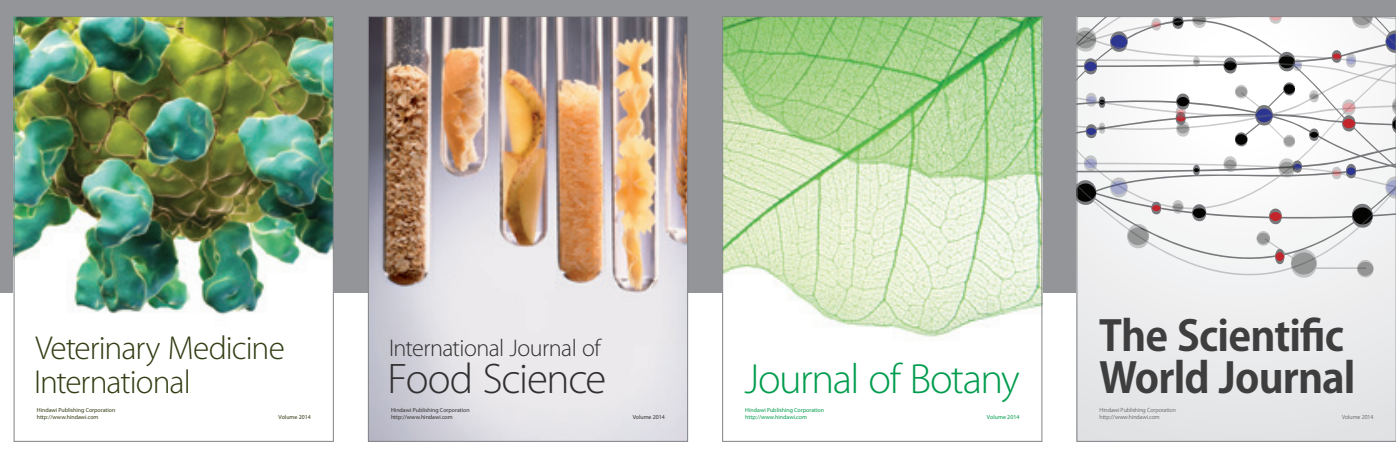

The Scientific World Journal
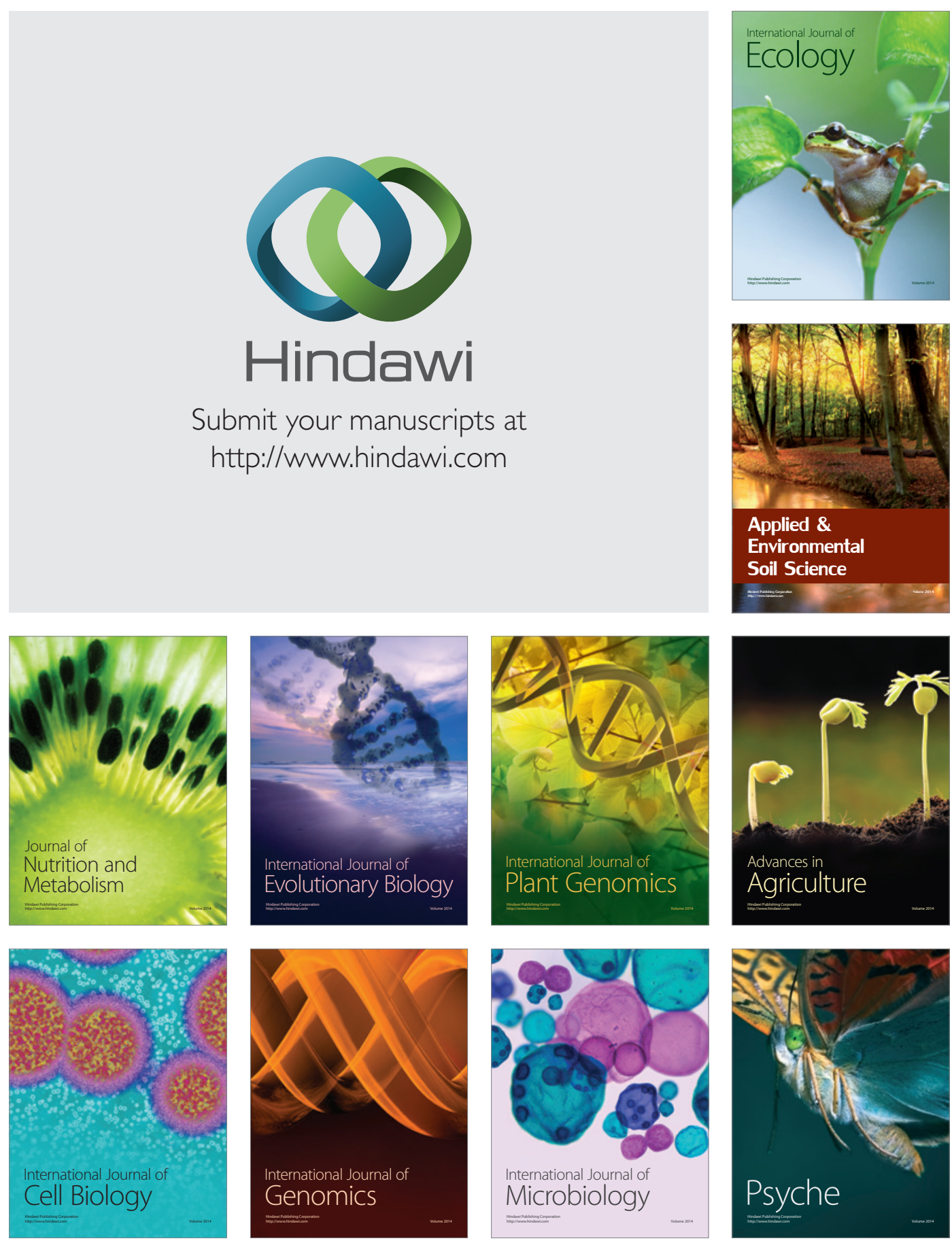